
\title{
IJBF SEPARATE LEGAL ENTITY UNDER
SYARIAH LAW AND ITS APPLICATION ON ISLAMIC BANKING IN MALAYSIA: A NOTE ${ }^{1}$
}

\author{
Zainal A. Zuryati, Mohamed Yusoff and \\ Ahmad N. Azrae \\ University Utara Malaysia
}

\begin{abstract}
The principle of separate legal entity - that is, after the incorporation of a company, it is regarded as an artificial person or juridical person who has the rights and responsibilities similar to a living person - has been widely accepted and applied in the world of business, trade and industry. In Malaysia, an Islamic banking institution is incorporated under the Companies Act 1965 where after its incorporation, it becomes a legal entity separated from its members and shareholders. In the case of Bank Islam Malaysia Berhad v. Adnan bin Omar (1994), the court held that Bank Islam Malaysia Berhad is a corporate institution created by statute. This case has been decided based on civil law system, not under the Islamic legal system. Since the products offered by an Islamic banking institution is solely in harmony with Islamic principles, one fundamental legal question yet to be resolved is whether the principle of separate legal entity is recognised under the Syariah law. This paper aims to discuss the issue of separate legal entity in Islam and its application to the Islamic banking institutions.
\end{abstract}

Keywords: separate legal entity, Islamic banking institutions, Syariah, juridical person, company

JEL Classification: K29

1 Editors' Note: This article is not on the operational aspects of banking as all our accepted articles have been over the last six years, but on the lacuna in law as to what is an Islamic bank. It is important enough to be included in this journal as this article points to a fundamental legal problem of recognition of Islamic bank as a legal persona. It appears that the term 'Islamic Bank' that can be traced to the first Islamic bank founded in 1963 has had no historical precedent in Islamic laws, and remains yet to be formally recognized in Syariah laws some 45 years after this entity has been invented and nurtured over the years. 


\section{Introduction}

One of the important elements in the common law concept of separate legal entity is that once a company has been incorporated, it will be considered as 'a person'. The corporation inter alia has the right to sue and to be sued, own property in its name and it is separate from the owner or shareholders of the corporation. The liability of the owner or the shareholder is limited to only the value of shares invested in that particular company. In Islam, there are views concerning this legal matter. The traditional Islamic jurists opinion is that the principle of separate legal entity does not exist in Islam. It is for a very simple fact that a company which is regarded as 'a person' is only a fictitious person and only an imaginary person, as such, has no capacity to engage in any commercial transaction. This is one view. Besides, if a company or the fictitious entity is declared insolvent, the creditors have only the rights over the assets of the company which is only registered under the imaginary person whereby if the assets are not sufficient to settle the amount, it is simply written off and cannot be claimed from anyone.

It is therefore pertinent to determine the existence of the principle of separate legal entity in Syariah and its application to Islamic banking institutions in Malaysia. In sections 2 and 3, we examine the grounds for this legal entity within the English system of laws and its growth in Malaysia. In sections 4 and 5, the reader will find a discussion of the historical development of bodies outside of a real person with legal recognition given under the Syariah laws. There it is clear that there is a clear difference of opinion for and against the recognition of a legal person outside that of a real person although there are such bodies - not banks - that had been given such recognition in historical time by jurists. We discuss the need for clarity by way of some an initiative to arrive at a ruling to give recognition of legal persona to the banking institutions in Malaysia.

\section{The Principle of Separate Legal Entity under Common Law}

A company is a corporation. A corporation is a succession or collection of persons having at law an existence, rights and duties, separate and distinct from those of the persons who are from time to time its members (Keenan and Bisacre, 2005, p. 2). A corporation carries with it several distinguishing features, namely it is a persona at law, i.e. an artificial person; and it has perpetual succession, i.e. the company carries on and is not dissolved despite the changes in its membership since its existence is maintained by the constant succession of new persons who replace those who die or being removed.

The doctrine of separate legal entity was originated from the case Salomon v. Salomon \& Co. Ltd. [1897]. The facts in this case disclosed that a company had been incorporated by Mr. Salomon in which he and members of his family were the only shareholders. The issue arises when the company's business turn to be a failure. The value of the assets was insufficient to pay out both $\mathrm{Mr}$. 
Salomon and the company's other creditors. Consequently, the creditors raised an issue whereby they argued that Mr. Salomon should not receive the payment from the company because the degree of control he exercised over the company.

It was held by the House of Lords that despite Mr. Salomon having the control over the company, it was neither his agent nor trustee. This is because, a company was treated as operating the business in its own right, and as being separate from its controller, i.e. in this case of Mr. Salomon. Therefore, the charge given by the company to Mr. Salomon was valid and he was entitled to be paid his debt even though other creditors of the company would not be paid because the company had insufficient assets to pay all its creditors.

Thus, it shows that a company is a legal person separate and distinct from its individual members or directors as in the words of Cave J in Re Sheffield \& South Sheffield Yorkshire Permanent Building Society, In Liquidation [1889]: 'a company is a legal persona just as much as an individual'.

In Macaura v. Northern Assurance Co. Ltd. [1925], Mr Macaura, had formed an estate company. Thereupon, he sold his owned timber estate for $£ 42,000$ to the estate company, whereby the purchase money was paid by the company in the form of issuance of 42,000 fully paid shares of 11 each. Macaura had effected an insurance policy on the timber in his own name, and not in the company's name. Eventually, on 23 February 1922, most of the timber was destroyed by fire. Thus, Macaura claimed under his insurance policies. However, it was ruled by the court that Macaura have no insurable interest. The insurance policy effected by him could only be on the basis of a creditor or a shareholder of the company, which neither two has an insurable interest in the assets of the company based on the principle that a company is an independent entity.

A company also has perpetual succession despite of the death of its shareholders. In Lee (Catherine) v. Lee's Air Farming Ltd. [1960], the facts disclosed that in 1954, Mr. Lee had formed the respondent company carrying on the business of crop spraying from the air. Mr. Lee owned 2,999 of the company's $3,000 £ 1$ shares. Apart from that, he also was the company's governing director whereby he had appointed himself as the only pilot of the company at a salary arranged by himself. In March 1956, Mr. Lee was killed while piloting an aircraft during the course of top-soil dressing. The appellant want to claim compensation from the company as the employer of her husband under the New Zealand Workers' Compensation Act 1922. The issue for determination was whether there existed the relationship of employer and employee between the company and Mr. Lee. The court held in favour of appellant and she was entitled to compensation. Following the grounds of the decision in Salomon's case, Mr. Lee was employed by the company in the sense required by the Act 1922 .

According to Keenan \& Bisacre (2005, p. 27), the principle set out in the above case has also led to the use of the term 'the veil of incorporation, which is said to hang between the company and its members and in law at least, act as a screen between them.

Under certain circumstances, this doctrine of separate legal entity produces what appear to be unjust and purely technical results. As a result, judges tend 
to come out under a moral or intellectual pressure to sidestep the principle of separate legal entity and produce a result which seems more 'just' (Pettet, 2005, p. 24). There are many reported cases that show the attitude of the judges to by-pass the precedent of Salomon's case in order to achieve justice by 'lifting' or 'piercing' the corporate veil (Re A Company (1985) at p. 241; Creasey v. Breachwood Motors Ltd. [1992] at p. 647).

Lord Denning MR suggested that the corporate veil could be lifted, that the companies were in reality a group, and should be treated as one (DHN Ltd. V. Tower Hamlets [1976]). On the other note, the House of Lords criticized Lord Denning's approach and held that the corporate veil could only be lifted in this way in circumstances where the company is a 'façade' (Woolfson v. Strathclyde DC (1978)).

In Adams v. Cape Industries plc [1990], the court gave strong support to the idea that there is really only one well-recognised exception to the rule prohibiting the piercing of the corporate veil. That is 'it is appropriate to pierce the corporate veil only where special circumstances exist indicating that it is a mere façade concealing the true facts. In Trustor AB v. Smallbone \& Ors. (No. 3) [2002], Morritt V-C held that the court would be 'entitled to pierce the corporate veil and recognize the receipt by a company as that of the individual in control of it if the company was used as a device or façade to conceal the true facts thereby avoiding or concealing any liability of those individual', and that on the facts this was satisfied.

\section{Separate Legal Entity under Malaysian Law}

This doctrine established in English law has received its application in Malaysia via the Companies Act 1965 (Act 125). Section 16(5) laid down the effect of its incorporation, namely:

- A company shall be regarded as a body corporate, capable of exercising all the functions of an incorporated company.

The term 'body corporate' is not defined under the Companies Act 1965. However, generally it covers both the 'companies' and 'corporation'. Both of these terms are defined under Section 4 of Companies Act 1965 which will be discussed later on. 'Corporation' is one of an artificial legal person (Zuhairah Ariff, 2003). According to Salleh Abas FJ, it is 'artificial' the company's legal persona is the result of statutory acts of the Registrar of Companies under s. 16 of Companies Act 1965 (Tan Lai v. Mohamed Bin Mahmud [1982]). In addition to that, Zakaria Yatim, J in People's Insurance Co (M) Sdn Bhd v. People's Insurance Co Ltd \& Ors [1986] held that under the ordinary rules of law, a parent company and its subsidiary company, even a wholly owned subsidiary company, are distinct legal entities. 
In one of the Court of Appeal's decision, it was held inter alia that even though an individual is the director of two companies, both companies possesses two different entities (Nanyang Union Sdn. Bhd. v. Gloveline Industries (M) $S d n$. Bhd. [2006]). The fact in the present case disclosed that Mr. Radwan Alami was the director of two companies; namely Gloveline Industries (M) Sdn. Bhd. and Safeline Industries (M) Sdn. Bhd. Nevertheless, both these companies are not the same as each company has their own separate entity.

- A company will have the right of suing and being sued.

In Lee Eng Eow (as director of Lee Guat Cheow \& Co Sdn Bhd) v Mary Lee (as executrix of the estate of Low Ai Lian) \& Ors [1999], the Court of Appeal had laid down the statutory effects of an incorporation, in that an incorporated association has a legal personality of its own apart from the persons who comprise it; even though it is not specifically provided in the Companies Act 1965. If a director breaches his duty to the company, it is the company who has the right to sue him. A member cannot sue the director on the company's behalf. Similarly, if a contracting party breaches his contract with the company, it is the company who has the right to sue the contractor. A member of the company cannot sue on the company's behalf to enforce a company's rights. This rule is known as the 'proper plaintiff rule' or the rule in Foss v. Harbottle (1843).

- A company will have perpetual succession.

To illustrate on this point, in the case of Abdul Aziz Bin Atan v. Ladang Rengo Malay Estate Sdn. Bhd. [1985], despite changes in the membership, the corporate entity continues unchanged. In Re Noel Tedman Holdings Pty Ltd [1967], the company may even continue to exist despite the death of all its shareholders and directors.

- A company will have the power to hold land and other property.

Article 9 of the Third Schedule to the Companies Act 1965 provides that a company possesses the power to purchase, take on lease or in exchange, hire and otherwise acquire any movable or immovable property. Besides, such rights are also conferred onto states by the National Land Code, where section 43(b) conferred on the State Authority with the power to dispose the land to the corporations.

Even though section 16(5) of Companies Act 1956 only mentions the right to own land, a company also possesses the right to own other sort of property (Tan Cheng Han, 2005). The property will be treated as the company's own and not the shareholder. Therefore, even if a person owns all the shares in the company, he does not own the company's property nor does he have any legal or equitable interest therein (Macaura v. Northern Assurance Co. Ltd. [1925]). 
- The liability on the part of the members to contribute to the assets of the company in the event of its being wound up are provided by the Companies Act 1965.

For example, according to s. 214(1)(d) of Companies Act 1965, in the case of a company limited by shares, the liability of its members is limited to the amount unpaid on his or her shares in the company. This was noted as one of the benefit enjoyed by the members of the limited company (Rachagan et al., 2005).

In other words, section 16(5) of Companies Act 1965 adopted the principle of separate legal entity as embodied in Salomon's case; i.e. the creation of a person in the eyes of the law upon incorporation of a company.

Similarly, under Common Law system, the Malaysian cases also accepts the principle of lifting the corporate veil. Peh Swee Chin, SCJ in Yap Sing Hock \& Anor v. Public Prosecutor [1992] said that: "Such veil has been lifted by statutes, e.g. the Companies Act 1965 itself or by the courts for certain specific purposes. The lifting of the veil clearly constitutes a violation of the primary principle but this has come to be treated correctly as an exception to the primary principle with such exception being subject to the parameters and perimeters indicated by the statutes or by the specific purposes so far indicated by the courts when lifting the veil".

To highlight on this point, we could refer to the case of Aspatra Sdn Bhd \& 21 Ors v. Bank Bumiputra Malaysia Bhd \& Anor [1988] where the majority of Supreme Court held that the lifting of the corporate veil in a group of companies in order to do justice, particularly when there is an element of fraud involved, was proper to expose the true owner of the company's assets (i.e. Lorrain Osman) in granting a Mareva injunction. In this case, the respondents had brought an action against Lorrain Osman, who was a director of the first respondent and the chairman of the second respondent, for the total sum of $\$ 27,625,853.06$ which they claimed to be secret profits made by Lorrain without their knowledge and approval. The respondents also made an ex parte application for a Mareva injunction to restrain Lorrain from transferring his assets out of jurisdiction and also for an order of discovery for Lorrain to disclose the value, nature and whereabouts of all his assets.

The fact disclosed that only 32 out of 21,796,395 shares in the appellant companies did not belong to Lorrain. He also exercised the effective or sole control of the companies by holding more than 99 percent of the total paid up capital of the 22 appellant companies. In addition, Lorrain also was a director in 15 of them. Based on this, the learned judge lifted the corporate veil to see whether the companies and their shareholders were in fact the same entity. The secret profits received by Lorrain were not denied on affidavit evidence; only the legal capacity under which Lorrain had received them was being contested. No doubt that it was admittedly an element of fraud in the receipt of the secret profits whatever might be the capacity in which Lorrain had received them. Thus, it is sufficient for the court to lift the corporate veil for the purpose of determining whether the assets of the companies are really owned by them as envisaged in Salomon's case [1897] and section 16(5) of the Companies Act 1965. 


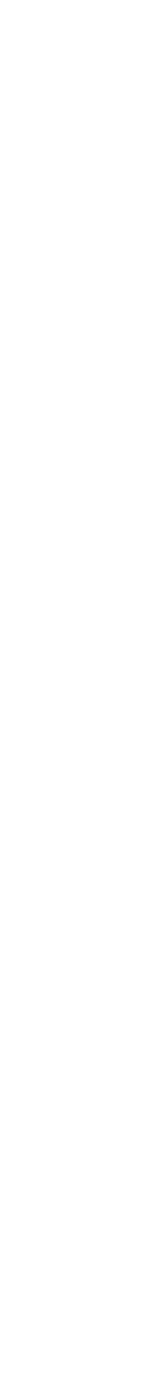

Although the learned judge did not say so expressly in his judgment, he in fact found the existence of such an abuse from the very structure of the companies after lifting the corporate veil. The learned judge found that Lorrain was the alter ego of the companies, and the assets of the appellant companies are in fact and in law Lorrain's assets.

Therefore, we may conclude that there are two types of person recognized by the law. The first one being the natural person or human beings; and the second would be the artificial person (Tan Lai v. Mohamed Bin Mahmud [1982]), which includes any being other than human being which the law recognized as having duties and rights. One of the most recognized artificial person is the corporation. Thus, we can see that the doctrine of separate legal entity is a fundamental legal principle which draws a distinction between an incorporated company and those people who have a control over it. A company will continue unchanged even if the identity of the participants in it changes (Aiman Nariman et al., 2002).

\section{The Principle of Separate Legal Entity and Syariah Law}

The principle of separate legal entity as introduced under the common law system finds no express provisions from any Syariah law resources. Zuhairah Ariff (2003) noted that some of the modern jurists of fiqh like Mustafa Ahmad al-Zarqa, Muhammad Abu Zuhrah and etc. justify the existence of entity other than human being as a legal person based on the theory of fiqh known as aldhimmah. 'Al-dhimmah' basically means 'guarantee' or 'accountable' (Nasri Naiimi, 2007).

According to Al-Kabashi (1989), some jurists view that the term aldhimmah and al-ahliyyah (capacity) as synonymous, both of which represent the entity that have rights, bear responsibilities and obligation. Thus, if an entity (al-dhimmah) is recognized to be in existence, either artificial or real, it will have a certain capacity (al-ahliyyah) and therefore will be subjected to certain obligations (iltizamat).

Nevertheless, this opinion was heavily criticised by the majority of the jurists because al-dhimmah refers to anything which has attributes of human being that denotes to it rights and responsibilities (al-Izibn, 660H, al-Bahuti 1041H, Ibn 'Abidin, 1252H.). Besides, al-Bazdawi (483H) and al-Nawawi, $(676 \mathrm{H})$ opined that al-dhimmah is a ' $z a t$ ' which is real and not fictitious, since the Syariah only imposed obligations and rights on real person. Moreover, the term al-dhimmah is not applicable at all and it has no relevancy in relation to interpretation of liability and obligation (al-Tahanawi, 1996).

However, the modern jurists like Taqi Usmani propagate the existence of the principle of separate legal entity under Syariah law based on precedents of other Islamic institutions and practice like waqf, masjid (mosque), baitul mal, joint stock, inheritance under debt and $A l A b d$ al-Ma'thoon (the slave who is permitted by his master to trade). Briefly, his argument as the basis for the existence of separate legal entity will be discussed.

According to Taqi Usmani, waqf is a legal and religious institution wherein a person dedicates some of his properties for a religious or a charitable purpose, 
creating separate legal entity. The properties, after being declared as waqf, no longer remain in the ownership of the donor. The beneficiaries of a waqf can benefit from the corpus or the proceeds of the dedicated property, but they are not its owners (Taqi Usmani, 2006 at p. 105). Muslim jurists (fuqaha') have treated waqf institution as separate legal entity based on two rulings; first, if a property is bought by using the waqf's money, the property does not become part of waqf, but become the property owned by the waqf institution. In other words, it demonstrates that the waqf institution may own a property. Another example given by him is that any donation given to the masjid, the donation belongs to the masjid and not become part of waqf. Furthermore, according to Ahmad alDardir, a distinguished Maliki jurist, a bequest made in favour of a mosque is accepted in Islam.

Another precedent that formed the basis for Taqi Usmani's (2006, pp. 105106) argument for the existence of separate legal entity in Syariah law is the baitul mal. According to him, Imam Al-Sarakhsi, the well-known Hanafi jurist, in his work "Al-Mabsut" stated that baitul mal has some rights and obligations which may possibly be undetermined. Al-Sarakhsi also pointed out that "If the head of an Islamic state needs money to give salaries to his army, but he finds no money in the Kharaj department of the Baitul-mal (wherefrom the salaries are generally given) he can give salaries from the sadaqah (Zakat) department, but the amount so taken from the sadaqah department shall be deemed to be a debt on the Kharaj department". Based on the views of al-Sarakhsi (1986) in alMabsut, it clearly shows that a department may borrow and indebted to another department.

Furthermore, the principle in a joint stock company which is found in the Fiqh of Imam Shafi ' $i$, also formed the basis of Taqi Usmani's argument on the separate legal entity in Islam. It is a settled principle of Shafi 'i School that if more than one person run their business in partnership, where their assets are mixed with each other, the zakat will be levied on each of them individually. However, the zakat will be payable on their joint-stock as a whole, so much so that even if one of them does not own the amount of the nisab, but the combined value of the total assets exceeds the prescribed limit of the nisab, zakat will be payable on the whole joint-stock including the share of the former, and thus the person whose share is less than the nisab shall also contribute to the levy in proportion to his ownership in the total assets. He was not subject to the levy of zakat, had it been levied on each person in his individual capacity. The same principle, which is called the principle of "Khultah-al-Shuyu" is more forcefully applied to the levy of zakat on the livestock. Consequently, a person sometimes has to pay more zakat than he was liable to in his individual capacity, and sometimes he has to pay less than that. This principle of "Khultah-al-Shuyu" which is also accepted to some extent by the Maliki and Hanbali schools with some variance in details, has a basic concept of a juridical person underlying it. It is not the individual, according to this principle, who is liable to zakat. Again, it is the 'joint-stock' which has been made subject to the levy. It means that the 'joint-stock' has been treated a separate entity which is very close to the concept of a 'juridical person' (Taqi Usmani, 2006, pp. 106-107). 
Lastly, when a deceased leaves liabilities exceeding his property, this property is neither owned by the deceased, nor is it owned by his heirs, for the debts on the deceased have a preferential right over the property as compared to the rights of the heirs. It is not even owned by the creditors, because the settlement has not yet taken place. They have their claims over it, but it is not their property unless it is actually divided between them. Being property of nobody, it has its own existence and it can be termed a legal entity. The heirs of the deceased or his nominated executor will look after the property as managers, but they are not the owners. If the process of the settlement of debt requires some expenses, the same will be met by the property itself (Taqi Usmani, 2006, p. 107).

The basis of the opinion for the existence of the principle of separate entity by Taqi Usmani however is heavily criticised in a book entitled "The Concept of Limited Liability - Untenable in Shariah" by Mujlisul Ulama of South Africa (http://books.themajlis.net/node/251). On waqf, it is refuted and argued that the assets purchased with the income of a waqf do not become part of the original waqf property for the simple reason that for anything to become waqf there has to be a 'waaqif' (a human being who dedicates the asset in the Path of Allah (God) as waqf). The waaqif of the waqf property specifically and expressly made the property waqf so that it could be employed to generate income for distribution to whatever charitable cause he/she (the waaqif) had designated. If the income of the waqf too has to become waqf automatically, the very aim and purpose of the waqf will be defeated and it will be devoid of utility. This is a dissenting view.

As for masjid, it is concurred that the ownership vests in Allah s.w.t. and Allah is not fictitious. Ownership of the masjid in this context means ownership of the Owner of the masjid. Allah s.w.t. who is the true owner of the masjid becomes likewise the owner of all assets made waqf for the expenditure of the masjid, and of all income generated by these waqf assets. As such, it negates the idea of the waqf being a fictitious entity like the common law principle of separate legal entity when the Syariah law emphasises the real ownership of the waqf to Allah s.w.t.? Is it not against the Syariah principles to negate Allah's ownership for relegating waqf to the limbo of fiction merely for substantiating the concept of separate legal entity or 'juridical person'?

The argument applying baitul mal as the basis for the recognition of separate legal entity is also been criticised by Mujlisul Ulama of South Africa. The different classes of wealth such as zakat and kharaj have to be expended in different avenues or for different purposes. If, for example, zakat money is used to construct a masjid, the obligation of zakat will not be discharged. If zakat money is thus spent in a category of expenditure which does not result in the discharge of the zakat obligation, it (zakat) will have to be made good by person who had used the funds for another purpose. This is not exclusive with the baitul mal. This law applies to everyone. The Khalifah is empowered by the Syariah law to take money from one category of funds and utilize it for a different purpose other than for what the money has to be used for according to the Syariah law. But in relation to the Khalifah such use is not misappropriation because the Shariah law permits this. However, when later funds of the particular kind are received, 
the Khalifah has to replace it to ensure that correct distribution is achieved. It is simply an issue of replacing the funds which the Khalifah had borrowed by virtue of the right the Syariah law has given him. The inanimate vaults in which are kept the funds do not lend. The Khalifah does not represent the baitul mal. He does not contract on behalf of the baitul mal which has no such capacity. He represents Allah s.w.t. and acts in terms of the mandate assigned to him by Allah s.w.t. The Khalifah is not in need of a concept such as 'separate legal entity' to carry out his mandate.

The obligation of zakat only applies to Muslims. Zakat will not be obligatory, according to the Shafi'e Mazhab on the joint stock owned by a Muslim and a non-muslim. If the stock of a non-Muslim and the stock of a Muslim are combined, khultah has taken place. If the obligation of zakat devolves on the joint inanimate rice and barley which were mixed or on any other combined stock, it would logically follow that zakat will have to be paid regardless of one partner being a Muslim and one a non-Muslim. Only the Muslim will pay zakat on his share of the mixture. The non-Muslim will not pay zakat on his share of the admixture regardless of the incidence of khultah. If the joint stock was truly a separate entity or a juridical person in the Western conception of the term, then zakat should have been obligatory on the stock by virtue of the principle of khultah regardless of the faiths of the owners of the joint stock. Faith does not apply to the inanimate 'juridical person' (theMajlis.net). Imran (2003, p. 117) expressly stated that artificial person or juridical person cannot perform religious duties including zakat. It is therefore meaningless to portray the joint stock as a juridical person and divert the obligation of zakat from the joint stock to only the Muslim.

Imran (2003) further opposed the existence of separate legal entity in Syariah law, though termed it as fictitious person or artificial person. The concept of separate legal entity that a company is a fictitous person relied on the instances of waqf, baitul mal and the estate of deceased has been regarded as misplaced assertions by modern Muslim jurists. According to him, the concept of syarikah will lose its significance if the separate legal entity concept acknowledged in Syariah law. In consequence, the acceptance of the principle will shatter the whole structure and violates the fundamental principles of Syariah law particularly law of contract. Hence, there is a strong opposition to the concept of legal persona for a corporation.

\section{Islamic Banking Institution in Malaysia}

The establishment of Islamic banking institutions reflects the desire of Muslims to live financial aspects of their lives in accordance with the teaching of Islam, as interpreted by a majority of scholars. Practically, the emergence of Islamic banking in Malaysia can be traced back to 1960s. Nevertheless, much of their principles are derived from the Qur'an and the Sunnah of the Prophet Muhammad p.b.u.h. more than 1400 years ago, so it is claimed by the majority opinion now prevalent on this institutional practices. 
Islamic Banking Act 1983 (Act 276) (hereinafter referred to as IBA) served as the legal basis for the establishment of the Islamic Banks in Malaysia. It is one of the few Islamic legislations passed by the Parliament to deal with the banking system. IBA came into effect on 7 April 1983. IBA had underlined on numerous occasions the control and supervision of the Central Bank of Malaysia ("Central Bank") over Islamic banks.

Apart from that, the Government also played a part to ensure the smooth running of the Islamic banks. Pursuant to this, the Government Investment Act 1983 was enacted at the same time of IBA to empower the Government to issue Government Investment Issue, which is a government security similar to a Treasury instrument issued based on Syariah principles.

Section 2 of IBA 1983 defines 'Islamic bank' as any company which carries on Islamic banking business and holds a valid licence; and all the offices and branches in Malaysia of such a bank shall be deemed to be one bank. Further, IBA defines 'Islamic banking business' as to mean banking business whose aims and operations do not involve any element which is not approved by the religion of Islam. Thus, the establishment of an Islamic banking institution is very much focused on the transactions that are Syariah's compliance.

Apart from that, IBA also stressed on the requirement of licensed Islamic bank. This has been highlighted under section 3 of IBA where it states that an Islamic banking business shall not be transacted in Malaysia except by a company which is in the possession of a licence in writing from the Minister authorizing it to do so. Therefore, if a company desires an authority to carry on Islamic banking business, it shall apply for such licence through the Central Bank to the Minister. Here, the Central Bank's role is to consider the application and to make recommendation to the Minister stating whether a licence should be granted or not and the conditions, if any, to be attached to the licence. Then, the Minister shall decide whether to grant a licence with or without conditions, or refuse a licence.

As discussed above, particularly in reference to IBA, the word 'company' has been used in numerous occasions to describe Islamic bank, for example under section 2 and 3 of IBA. Section 2 of IBA 1983 defines 'Islamic bank' as any company which carries on Islamic banking business and holds a valid licence; and all the offices and branches in Malaysia of such a bank shall be deemed to be one bank. This shows that an Islamic bank in Malaysia must be a company (Halsbury's Laws of Malaysia, Vol. 14, 2002 at p. 255). However, IBA did not define the term 'company' or 'corporation' itself (section 2, IBA 1983).

Nevertheless, the section 4 of the Companies Act 1965 define the term 'company' as to mean a company incorporated pursuant to the Companies Act 1965 or pursuant to any corresponding previous enactment. The same section also defines the term 'corporation' means any body corporate formed or incorporated or existing within Malaysia or outside Malaysia and includes any foreign company, but excluding four specific categories of corporation as enumerated in that section. Apart from that, section 2 of the Companies Act 
1965 also defines 'banking corporation' to mean a licensed bank, a licensed merchant bank and an Islamic bank.

All of this indicates that a banking institution, particularly Islamic bank, is a company incorporated under s. 16(5) of Companies Act 1965, and consequently the rule of separate legal entity which embodied in a company is also applicable to the Islamic banking institution. In addition to that, section 55 of the Companies Act 1965 states that since Islamic bank is incorporated under the Companies Act 1965, than it shall be subjected to both of the provisions under Companies Act 1965 and IBA 1983. But, in case of conflict or inconsistency between the two Acts, the provisions of IBA shall prevail.

This has been explained by Norhashimah Mohd Yassin (1997) while commenting on the case of Bank Islam Malaysia Bhd. v Adnan Bin Omar (unreported), where it deals with the issue of jurisdiction of Syariah Court over Islamic banking cases. The court in that case had decided that BIMB is a corporate body which has no religion, and consequently it is not within the jurisdiction of Syariah Courts. List II (State List) of the Ninth Schedule to the Federal Constitution stated that the Syariah Courts shall have jurisdiction only over persons professing the religion of Islam and in respect only of any matters included in the State List. NH Chan J held that the matter was rightly brought before the civil court because Islamic Institutions such as BIMB and Syarikat Takaful are corporate institutions created by statute and do not have a religion (Norhashimah Mohd Yassin, 1997 at p. cxcv-cxcvi).

Another interesting case which attracted the application of doctrine of separate legal entity in Islamic banking is the case of Dato' Hj Nik Mahmud bin Daud v. Bank Islam Malaysia Bhd. [1996]. The fact disclosed that a Bay' Bithaman Ajil financing agreement was entered into by plaintiff and BIMB to develop his piece of land in Kelantan. The land is held under the Kelantan Malay Reservation Enactment 1930; whereby section 7(i) prohibits any transfer or transmission or vesting of any right or interest of a Malay in reservation land to or in any person not being a Malay. The issue here is whether there is a transfer or a vesting of right or interest involving a non-Malay. This is due to the fact that BIMB is a bank with neither a Malay nor a native of Kelantan. However, to reconcile this matter and to enable the bank to register the charge, Schedule D of the 1930 Enactment allows Rulers in Council to grant Malay status to a bank for the purpose of registering a charge document (Norhashimah Mohd Yassin, 1997 at p. cc-cci).

\section{Suggestion and Conclusion}

Looking at the discussion above, it is clear that the issue on the existence of the principle of separate legal entity in Syariah law draws differences of opinions among the jurists. However, to draw back from the principle will definitely causing a huge impact on the Islamic banking system and institutions which already are so advanced and well accepted throughout the world. Even the 
dissenting jurists on the acceptance of separate legal entity in Syariah law (based on dhimmah, baitul mal, waqf etc) acknowledged the importance of justifying and accommodating the legal validity of a fictitious legal personality or separate legal entity under Syariah law whenever it is clashed (Imran, 2003, p. 17).

Hence, to reconcile the matter, it is indeed an urgent need to have a specific fatwa or Islamic injunction by the Muslim jurists on this matter, what more if it can be a collective fatwa of them to become an ijma' (considered consensus). As advocated by Taqi Usmani (2002), this ijtihad should preferably be undertaken by the Syariah jurists at a collective level, yet, as a pre-requisite, there should be some individual efforts which may serve as a basis for the collective exercise. Thus, it is worthy to note an opinion by Wahbah al-Zuhayli on "syarikah "inan" because the concept of syarikah "inan has become the basis for the establishment of Islamic banking institution throughout the world.

On the concept syarikah 'inan, there are several categories of companies which are akin to company under common law, namely, syarikah al-tawsiyyah albasitah (company limited by guarantee), syarikah al-musahamah, al-tawsiyyah bil-asham and zatul mas'uliyyah al-mahdudah (company limited by share). The various names of the syarikah/company limited by share are due to flexibility and compatibility of Islam based on the principle of 'urf (custom) to suit the changing nature of modern world of trade and business. The shareholders of these companies have limited liabilities according to the portion of shares held (Wahbah Zuhayli, 1995 at p 882-887) just as in English laws. However, Wahbah Zuhayli does not specifically state the principle of neither separate legal entity nor juristic person (syakhsiyah maknawiyah) on the nature of these companies, but it is inferential from the nature of the companies, there are similar to the principle of separate legal entity under common law. This is due to the fact that the basis for sharikah 'inan as propounded by Wahbah Zuhayli (2003, pp. 451452) is in fact a form of limited partnership.

According to Wahbah Zuhaily while referring to Ibn al-Mundhir that 'inan' is a form of partnership, where the partners share the capital, as well as profits and losses, is approved by consensus. These partners in a sharikah 'inan need not be equal in their contributions to capital, nor equal in their legal rights for using the property. Thus, one party may contribute more than another to the partnership, and one of the partners may have the exclusive right to run the affairs of the partnership. Given this potential for great variation in legal rights of dealing in the joint property, each party is only responsible for dealings that he himself performed. Thus, while they share the profits according to any rule they agreed upon in the contract, the only share losses in proportion to their contributions to the partnership's capital. The general rule is summarized thus: "profits are shared according to the parties' conditions, but losses are shared according to their shares in the capital" (2003, p. 452).

Henceforth, as an example, the establishment of Bank Islam Malaysia Berhad is founded on the principle of syarikah 'inan. According to Dato' Tajuddin Abdul Rahman, Managing Director of Bank Islam Malaysia Berhad, the Islamic bank is essentially an 'inan company, a separate legal entity based 
on the concept of AI-Musyarakah. The 'inan company is made up of a minimum two shareholders with no limit to the maximum number. It is a business entity, formed by having a group of shareholders, electing representatives to manage the company (board of directors) on the basis of Wakalah. At the same time the shareholders retain their management control (voting rights) in the company in proportion to their shareholding.

Even though Taqi Usmani is the champion of separate legal entity, he himself has some reservation on its application. The concern is that the company, while the liability of the shareholders are limited, being exploited as a vehicle of fraud. This is also the basis for the adversaries that the principle is incompatible with Syariah law. On the other hand, on the apprehension of the company being utilised for avoidance of law or fraudulent purposes, though understandable, may be dealt with the application of exception to principle of separate legal entity that is, lifting the corporate veil. Though the exception only exposes the 'real' person behind a company, the liability is still limited to the portion of his shares without extending to his personal properties. In other words, the exception to the principle of separate legal entity does not fully solve the problem of companies being used for fraudulent purposes.

To sum up, the Islamic banking institutions in Malaysia incorporated under section 16(5) of Companies Act 1965 is a separate legal entity, enjoying and having the rights and liabilities alike to the living person. The application of separate legal entity principle upon Islamic banking institutions in Malaysia is founded on the common law principle as propounded in the case of Salomon $v$ Salomon Co. Ltd. and is applied in toto. The questions of whether the principle is recognisable under Syariah law, whether in an unchanged or modified application of the principle should be practiced, are pertinent to be answered and analysed collectively by Muslim jurists (fuqaha') for further advancement of Islamic banking system.

Author statement: Zainal Amin Ayub Zuryati, Mohamed Yusoff and Ahmad Nasyran Azrae are teaching staff in the Faculty of Management and Law, University Utara Malaysia. E-mails: z.amin@uum.edu.my, zuryati@uum.edu. my and nasyran@uum.edu.my.

\section{References}

Ahmad Tajudin Abdul Rahman. (2000). Workings of an Islamic bank: Case study of Bank Islam Malaysia Berhad. At the Fourth International Conference on Islamic Economics, Banking and Finance Loughborough, United Kingdom August 13 - 15, 2000.

Aiman Nariman Mohd Sulaiman. (2005). Commercial applications of company law in Malaysia (2nd ed.). Singapore: $\mathrm{CCH}$ Asia Pte. Limited.

al-Kabashi, Al-Makashifi Taha. (1989). Al-dzimmah wa al-haq wa ta'thiruha bi al-mawt fi al-fiqh al-Islami: Dirasah muqaranah. Riyadh: Maktabah al-Haramayn. 
al-Tahanawi, Muhammad 'Ali. (1996). Kashshaf mustalahat al-funun wa alulum. Beirut: Maktabah Lubnan.

al-Zuhayli, Wahbah. (2003). Financial transaction is Islamic jurisprudence. Vol. 1. Beirut, Lubnan: Dar al-Fikr al-Mouaser.

al-Zuhayli, Wahbah. (1995). Fiqh dan Perundangan Islam Jilid IV. (Terjemahan oleh Md. Akhir Hj Yaacob et al.). Kuala Lumpur : Dewan Bahasa dan Pustaka.

Imran Ahsan Khan Nyazee. (2003). Islamic jurisprudence. Petaling Jaya: The Other Press, International Institute of Islamic Thought.

Keenan, D., and Bisacre, J. (2005). Smith and Keenan's company law (13th ed.). Harlow: Pearson.

Mohd. Ma'sum Billah (2006). Shariah standard of business contract. Kuala Lumpur: A.S. Noordeen.

Muhammad Taqi Usmani. (2002). An introduction to Islamic finance. The Hague: Kluwer Law International.

Mujlisul Ulama of South Africa. (2007). The concept of limited liability: Untenable in the Shariah. South Africa: Young Men's Muslims Association. Retrieved November 15, 2007 from http://books.themajlis. net/node/251

Nasri Naiimi. (2007, April). Peranan perundangan dalam merealisasikan konsep syirkah dalam pengurusan harta pusaka. Paper presented at the Persidangan Undang-undang 2007 'Undang-undang dan Etika: Menangani Cabaran Globalisasi, EDC-UUM, Sintok.

Norhashimah Mohd. Yasin. (1996). Islamisation/Malaynisation: A study on the role of Islamic law in the economic development of Malaysia: 1969-1993. Kuala Lumpur: A.S. Noordeen.

Norhashimah Mohd. Yasin. (1997). Islamic Banking: Case Commentaries Involving al-Bay' Bithaman Ajil [1997] 3 MLJ cxcii.

Padmanabha Rao, K.V. (2003). Company law of Malaysia (incorporation and management). Petaling Jaya: International Law Book Service.

Pettet, B. (2005). Company law (2nd ed.). Harlow: Pearson.

Rachagan, S., Pascoe, J., and Joshi, A. (2005). Concise principles of company law in Malaysia. Malayan Law Journal.

Shanthy Rachagan. (2002). Principles of company law in Malaysia. Malayan Law Journal.

Shams al-Din Al-Sarakhsi. (1406H/1986). Al-Mabsut. Beirut: Dar al-Ma'rifah.

Tan Cheng Han. (2005). Walter woon on company law (3rd ed.). Singapore: Sweet \& Maxwell Asia.

Taqi Usmani. (2006). The principles of limited liability. Retrieved from http:// www.meezanbank.com/knowledgecenter/knowledge-islamic-section -7-3. asp.

Taqi Usmani. (2007). Musharakah \& mudharabah: The principle of limited. Retrieved November 15, 2007, from http://www.darululoomkhi.edu.pk/ fiqh/ islamicfinance/limitedliability.html

Zuhairah Ariff Abd Ghadas. (2003, October). The myth of corporate personality: An overview from the common law and the Islamic law perspective. Paper 
presented at the International Conference on Harmonisation of Shariah and Civil Law, International Islamic University Malaysia.

Zuhairah Ariff Abd Ghadas. (1998). Islamic law of business organization: Corporations. Islamabad: International Institute of Islamic Thought and the Islamic Research Institute.

Zuhairah Ariff Abd Ghadas. (2007). Bank Negara Malaysia. Retrieved November 25, 2007, from http://www.bnm.gov.my/index. php?ch=174\&pg $=467 \& \mathrm{ac}=369$.

Zuhairah Ariff Abd Ghadas. Halsbury laws of Malaysia. Malayan Law Journal, 14, (2002). Remedies: Syariah Law.

Statutes:

Companies Act 19651965 (Act 125).

Federal Constitution of Malaysia.

Islamic Banking Act 1983 (Act 276).

National Land Code (Act 56).

Cases:

Abdul Aziz Bin Atan v. Ladang Rengo Malay Estate Sdn. Bhd. [1985] 2 MLJ 165.

Adams v. Cape Industries plc [1990] BCC 786 at p. 822.

Aspatra Sdn Bhd \& 21 Ors v. Bank Bumiputra Malaysia Bhd \& Anor [1988] 1

MLJ 97.

Bank Islam Malaysia Berhad v. Adnan bin Omar (unreported).

Creasey v. Breachwood Motors Ltd. [1992] BCC 638.

Dato' Hj Nik Mahmud bin Daud v. Bank Islam Malaysia Bhd. [1996] 4 MLJ

295.

DHN Ltd. v. Tower Hamlets [1976] 1 WLR 852.

Foss v. Harbottle (1843) 2 Hare 461.

Lee (Catherine) v. Lee's Air Farming Ltd. [1960] 3 All ER 420.

Lee Eng Eow (as director of Lee Guat Cheow \& Co Sdn Bhd) v Mary Lee (as executrix of the estate of Low Ai Lian) \& Ors [1999] 3 MLJ 481.

Macaura v. Northern Assurance Co. Ltd. [1925] AC 619.

Nanyang Union Sdn. Bhd. v. Gloveline Industries (M) Sdn. Bhd. [2006] 1 CLJ 873.

People's Insurance Co (M) Sdn Bhd v. People's Insurance Co Ltd \& Ors [1986] 1 MLJ 68.

Re A Company (1985) 1 BCC 99,.

Re Noel Tedman Holdings Pty Ltd [1967] Qd R 561.

Re Sheffield \& South Sheffield Yorkshire Permanent Building Society, In Liquidation [1889] 22 Ch 470, 476, 5 TLR 192.

Salomon v. Salomon \& Co. Ltd. [1897] AC 22.

Tan Lai v. Mohamed Bin Mahmud [1982] 1 MLJ 338.

Trustor AB v. Smallbone \& Ors. (No. 3) [2002] BCC 795 at p. 801.

Woolfson v. Strathclyde DC (1978) 38 P \& CR 521.

Yap Sing Hock \& Anor v. Public Prosecutor [1992] 2 MLJ 714. 